\title{
Methodological Principles of Research of the Phenomenon of Procrastination
}

\section{Методологічні засади дослідження феномену прокрастинації}

\author{
Olena Zhuravliova \\ Ph.D in Psychology, Doctoral Student, Department of Psycho- \\ logy and Sociology, Lesya Ukrainka Eastern European National \\ University, Lutsk (Ukraine) \\ ORCID ID: https://orcid.org/0000-0002-4889-0239 \\ Researcher ID: T-2567-2019 \\ E-mail: Zhuravlova.Olena@eenu.edu.ua

\section{Олена Журавльова} \\ Кандидат психологічних наук, докторант факультету пси- \\ хології та соціології, Східноєвропейський національний універ- \\ ситет імені Лесі Українки, м. Луцьк (Україна)
}

\section{ABSTRACT}

The author proves the relevance of the study of procrastination to be a stable personal construct. The consequences of the increased tendency of the individual to exhibit dilatory behavioral reactions are outlined.

The purpose of the article is to construct a theoretical and methodological base for a comprehensive study of the phenomenon of procrastination. The main methods of research were theoretical analysis and modeling, which formed the basis for determining the structure of this disposition.

The results of the theoretical study of the problem indicate the necessity to interpret procrastination as a holistic concept, the influence of which is in all

Address for correspondence, e-mail: kpnu_lab_ps@ukr.net Copyright: (c) Zhuravliova Olena

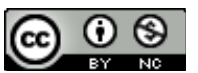


dimensions of the personality's life. The analysis of the essence of the studied concept makes it possible to point out its multidimensionality and determinability by a wide range of psychological, social and physiological factors. The basis for the creation of the model of personality of the procrastinator was the principles of the post-nonclassical scientific paradigm, the principles of systematic, structural, continuity and biopsychosocial approach of J. Angell. Due to the certain methodological approach, the author notes that procrastination at the macro-systemic level functions as a multidimensional integral stable personal formation, and in the subsystem sphere it is represented by psychosocial and biological substructures.

The psychosocial field of procrastination is considered as a set of individual personality traits that are formed and transformed by the inclusion of a person in a wide range of reference groups and the process of socialization in general. From the point of view of the author, the specified dimension of a person being predisposed to procrastination is manifested in his way of thinking, emotional experiences and peculiarities of behavior. Thus, within the psychosocial area, the cognitive-reflexive, affective-motivational and connective-regulatory levels of procrastinator functioning are distinguished.

The biological substructure contains two components: a neurophysiological (specific features in the activity of areas of the cerebral cortex of persons being predisposed to delaying important cases) and psychosomatic (specific somatic disorders associated with the individual's procrastination tendency).

Conclusion. Thus, an integral multilevel model of procrastination as a stable personal construct was formed, requiring further empirical verification.

Key words: procrastination, systemic unity, structural, continuity, psychosocial and biological substructure.

\section{Вступ}

Найважливішими характеристиками особистості для успішної адаптації в сучасних умовах мінливої соціальної реальності $€$ їі активність і здатність до ефективної саморегуляції. Водночас надмірна насиченість інформаційного простору та динамічність життя часто виступають детермінантами емоційної напруги індивіда та порушення здатності до оптимального структурування власного часу. Як наслідок, спостерігаємо стрімке зростання схильності людей до

(C) Zhuravliova Olena

DOI (article): https://doi.org/10.32626/2227-6246.2020-48.88-111 
прояву прокрастинації (ірраціонального відкладання важливих справ на невизначений термін) як однієї 3 неадаптивних захисних поведінкових реакцій. Деструктивність наслідків зазначеного феномену проявляється у широкому спектрі емоційних проблем (тривога, страх, депресія), соматичних порушень (головний біль, виснаження), труднощів у міжособистісних стосунках.

3 огляду на це, закономірним є високий рівень наукового інтересу до цього явища. Узагальнення результатів грунтовного теоретичного аналізу досліджуваної проблеми як у зарубіжній, так і у вітчизняній літературі дає підстави стверджувати, що попри наявність широкого спектра наукових поглядів щодо сутності прокрастинації, дискусійним i недостатньо висвітленим залишається питання структурної організації цього концепту та змістового наповнення його компонентів.

\section{Завдання статті}

Відтак, ключовим завданням нашої наукової роботи є конструювання методологічної бази в сукупності усіх рівнів методології загальної психології для комплексного вивчення прокрастинації як особистісного конструкту.

\section{Методи та методики дослідження}

У дослідженні здійснено теоретичний аналіз наукової літератури та застосовано метод моделювання для реалізації сформульованої задачі.

\section{Результати та дискусії}

Одним із найефективніших способів конкретизації змістового наповнення феномену прокрастинації вважаємо створення її теоретичної моделі, необхідної для ефективної організації подальшого емпіричного вивчення цього феномену. Поняття «модель» (від лат. «modelium» - зразок, образ, спосіб) Ю. Дмитрієва та В. Грязєва-Добшинська пропонують (c) Zhuravliova Olena

DOI (article): https://doi.org/10.32626/2227-6246.2020-48.88-111 
тлумачити як мисленнєво уявлюваний або матеріально реалізований аналог певного явища чи системи, що відтворює суттєві властивості досліджуваного об'єкта та може замінити його у процесі пізнання (Дмитриева \& Грязева-Добшинская, 2013). Подібне визначення представлено й у «Філософському словнику» А. Грицанова, на думку якого, зазначений термін слід інтерпретувати як об'єкт-замінник, що за визначених умов може заміщати об'єкт-оригінал, відтворюючи його основні характеристики (Грицанов, 1998: 435).

Отже, моделювання є інструментом наукового мислення, зорієнтованим на осягнення сутності реального явища (процесу, властивості) шляхом створення та дослідження його спрощеного зображення (умовного образу). Відтак, погоджуємося 3 твердженням, відповідно до якого цей метод певною мірою є різновидом абстрактно-логічного пізнання (Никандров, 2003). Для розкриття змісту поняття моделювання використовують різні категорії: "уподібнення», «символізація», «аналогія», «відображення», «відповідність», «наслідування» тощо. Як зазначає В. Штрофф, окреслений процес передбачає відтворення окремих сторін прототипу (Штрофф, 1996).

Отже, розробка моделі є міцним підгрунтям для: системного та всебічного вивчення сутнісних характеристик, принципів розвитку і взаємодії досліджуваного феномену з навколишньою дійсністю; визначення найоптимальніших способів управління об'єктом з огляду на попередньо сформульовану мету; прогнозування ймовірних прямих і опосередкованих наслідків реалізації впливу обраними засобами на досліджуваний параметр (Горстко, 1994). Л. Хоружа відзначає, що моделювання виконує ілюстративну, пояснювальну, критеріальну, евристичну, прогностичну й перетворювальну функції (Хоружа, 2004: 260). Отже, беззаперечною перевагою використання цього методу є можливість емпіричної апробації теоретичних положень, закладених у модель дослідником, у самостійно визначених ним умовах.

(C) Zhuravliova Olena

DOI (article): https://doi.org/10.32626/2227-6246.2020-48.88-111 
DOI: https://doi.org/10.32626/2227-6246.2020-48

Моделювання повинно здійснюватися 3 урахуванням усіх засад і принципів побудови науки. Значення методології для розвитку психологічного вчення важко переоцінити. Як зазначає В. Рибалка, вона є необхідним фундаментом для осягнення, пізнання й трансформації предмета психологіï, а поглиблення наукового знання за рахунок включення нових фактів і емпіричних даних, зафіксованих ученими, можливе лише при оновленні методологічних систем. Окрім цього, В. Рибалка акцентує увагу й на тому, що рух думки дослідника в межах методологічного простору у «вертикальному напрямку» передбачає сходження від конкретного (буття окремої людини) до абстрактного (світоглядних проблем, філософських категорій), і навпаки, що полегшує орієнтацію професійного психолога у власній науці (Рибалка, 2003).

Більшість науковців слідом за Е. Юдіним у вертикальній структурі методології виокремлюють чотири рівні: 1) вищий рівень філософської методології; 2) загальнонаукові принципи дослідження; 3) конкретно-наукову методологію; 4) методики і техніки дослідження (Юдин, 1978). Саме перші три щаблі цієї рівневої схеми складають основу для розробки інтегральної моделі прокрастинації, її емпіричної верифікації й інтерпретації отриманих даних (табл. 1).

Вищий рівень філософської методології у межах нашого дослідження представлений постнекласичною науковою парадигмою, яка зародилася наприкінці 80-х pp. XX ст. в результаті четвертої інформаційної революції, що призвела до масштабного впровадження в усі сфери суспільного життя новітніх засобів комп'ютерної техніки та комунікаційних технологій, а відтак, трансформувала характер отримання, зберігання й трансляції інформації соціальними суб'єктами (Иноземцев \& Удовик, 2011). Формування інформаційного суспільства не лише детермінуе зміни у специфіці комунікації всередині наукової спільноти, а й у структурній організації науки загалом.

(c) Zhuravliova Olena

DOI (article): https://doi.org/10.32626/2227-6246.2020-48.88-111 
Методологічні основи вивчення сутності прокрастинації

\begin{tabular}{|c|c|c|}
\hline Рівні аналізу & $\begin{array}{c}\text { Методологічний } \\
\text { інструментарій }\end{array}$ & Основні положення \\
\hline $\begin{array}{c}\text { 1. Вищий } \\
\text { рівень } \\
\text { філософської } \\
\text { методології }\end{array}$ & $\begin{array}{c}\text { Постнекласична } \\
\text { парадигма }\end{array}$ & $\begin{array}{l}\text { Прокрастинація трактуєть- } \\
\text { ся як багатомірна цілісність, } \\
\text { вплив якої прослідковується } \\
\text { в усіх вимірах життя людини }\end{array}$ \\
\hline \multirow[t]{3}{*}{$\begin{array}{c}\text { 2. Рівень } \\
\text { загально- } \\
\text { наукових } \\
\text { принципів } \\
\text { дослідження }\end{array}$} & $\begin{array}{c}\text { Принцип } \\
\text { системності }\end{array}$ & 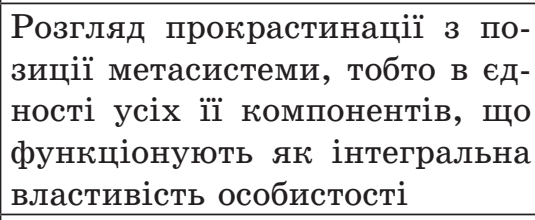 \\
\hline & $\begin{array}{c}\text { Принцип } \\
\text { структурності }\end{array}$ & $\begin{array}{l}\text { Тлумачення прокрастинації } \\
\text { як цілісного утворення, при- } \\
\text { рода якого встановлюється } \\
\text { шляхом визначення сутності } \\
\text { його диференційованих еле- } \\
\text { ментів та існуючих взаємо- } \\
\text { зв'язків між ними }\end{array}$ \\
\hline & $\begin{array}{c}\text { Принцип } \\
\text { континуальності }\end{array}$ & $\begin{array}{l}\text { Інтерпретація прокрастинації } \\
\text { як нестатичної характеристи- } \\
\text { ки особистості, схильної до } \\
\text { кількісних трансформацій із } \\
\text { плином часу }\end{array}$ \\
\hline $\begin{array}{l}\text { 3. Рівень } \\
\text { конкретно- } \\
\text { наукової } \\
\text { методології }\end{array}$ & $\begin{array}{c}\text { Біопсихосоціаль- } \\
\text { ний підхід }\end{array}$ & $\begin{array}{l}\text { Вивчення прокрастинації } \\
\text { точки зору багатомірного кон- } \\
\text { структу шляхом експлікації й } \\
\text { опису специфіки їі психоло- } \\
\text { гічного, соціального та біоло- } \\
\text { гічного вимірів }\end{array}$ \\
\hline
\end{tabular}

Чітка диференціація та спеціалізація, властиві попереднім етапам розвитку наукового знання, заміщуються інтенсивними процесами синтезу і кооперації (Броннікова, 2015). Отже, однією з ключових особливостей постнекла(C) Zhuravliova Olena DOI (article): https://doi.org/10.32626/2227-6246.2020-48.88-111 
сичної парадигми є міждисциплінарність, тобто поєднання різних наукових галузей у межах вивчення одного об'єкта. Водночас I. Чернікова вказує на глобальніші зміни, що виявляються у стрімкому розвитку трансдисциплінарності «виходу» вченими за межі конкретних наук (Черникова, 2007). Саме такі дослідження здатні «переносити» схеми, категорії, стратегії з практики однієї наукової сфери в іншу (Броннікова, 2015). Тобто, це своєрідна єдність знань за межами конкретних дисциплін.

Розвиток методології цього періоду передбачає «поєднання непоєднуваного» (Асмолов, 2015: 22), «коли наукові школи еволюціонують із «чистих ліній» у змішані дослідницькі рухи» (Асмолов, 2015: 29), стрімко стираються межі між фундаментальними та прикладними дисциплінами. Об’єднання природничих, соціогуманітарних i технічних учень зорієнтоване, насамперед, на вивчення смисложиттєвих проблем загальнолюдського значення і спрямоване на пошук оптимальних способів їх вирішення. Отже, першочерговою умовою розвитку науки у межах цієї парадигми є ï практичне значення для соціуму, подолання існуючої прірви між теорією і практикою, відтак, ідеться про якісно новий етап інтеграції знань у суспільство (Броннікова, 2015).

Відображені закономірності представлено у працях М. Гусельцевої, яка зазначає, що постнекласичний період розвитку психології грунтується на інтенсивності наукових комунікацій і прагненні дослідників до узгодження різноманітних психологічних теорій (Гусельцева, 2005). Підтримуючи висловлені вченою ідеї, В. Мазілов критикує застосування у межах сучасних досліджень постулату Т. Куна щодо неспівмірності існуючих сьогодні наукових парадигм й акцентує увагу на необхідності кооперації (Мазилов, 2001). Л. Радзиховський зазначає, що джерелом кризи у психології є монізм (Радзиховський, 1989). Ідеї «методологічного плюралізму» підтримує у своїх працях і С. Смирнов (Смир(c) Zhuravliova Olena

DOI (article): https://doi.org/10.32626/2227-6246.2020-48.88-111 
нов, 2005). Отже, основне завдання вчених А. Асмолов убачає в тому, щоб «знайти між різними теоріями комунікацію i діалог, а не доводити, що може існувати лише одна монопсихологія» (Асмолов, 2015: 19).

Одним із ключових у межах постнекласичної науки $е$ принцип холізму. Такий тип мислення грунтується на розумінні людського буття як цілісності (єдності тілесного, душевного та духовного вимірів). Відтак, саме ця парадигма є ефективним підгрунтям для аналізу багатомірних концептів із високою онтологічною та гносеологічною складністю (Воропаева \& Чик, 2015). Окрім того, це спроба вчених перейти від схеми жорсткого детермінізму до індивідуальних i неповторних проявів психічного, поліваріантних сценаріїв розвитку (Татенко, 2009).

Отже, аналіз низки праць (Гусельцева, 2005; Волков, Назаров \& Лукьянов, 2015; Нестик, Ж Жравлев \& Юревич, 2016), присвячених окресленій проблематиці, дає змогу виокремити принципові характеристики зазначеної парадигми.

1. Мережевий спосіб організації знань - єдність низки наукових концепцій, що грунтуються на різних дихотоміях (внутрішнє-зовнішнє, об'єктивне-суб'єктивне, природниче-гуманітарне) й описують окремі аспекти психічної реальності. Відтак, у контексті вивчення прокрастинації вважаємо доречним поєднання ідей щодо їі сутності, запропонованих представниками різних психологічних учень: біхевіоризму, когнітивної психології, психоаналізу, а також теорії тимчасової мотивації.

2. Міждисциплінарний дискурс - зближення різних дисциплін і зникнення критерію, що є основою маркування теорії як психологічної, а не соціологічної чи фізіологічної. Такий погляд призводить до створення цілісної та багатомірної картини знання. 3 огляду на це, розкриття сутності феномену прокрастинації, на нашу думку, потребує іï тлумачення не лише з точки зору психологічних механізмів, а

(C) Zhuravliova Olena

DOI (article): https://doi.org/10.32626/2227-6246.2020-48.88-111 
DOI: https://doi.org/10.32626/2227-6246.2020-48 2020. випуск 48

й нейробіологічних закономірностей функціонування людини i, навіть, із позиції деяких економічних теорій (теорія дисконтування).

3. Парадигмальна толерантність - прояв поваги до відмінних поглядів іншої особистості, що є необхідною умовою конструктивного наукового дискурсу.

4. «Легалізація внутрішньосуб'єктного досвіду» - визнання провідного значення особистісного досвіду індивіда у процесі пізнання, зростання значущості інтроспекції як методу осягнення дійсності. Відтак, закономірним є зростання ваги індивідуальних властивостей науковця, зокрема, здатності до нелінійного та цілісного мислення.

5. Методологічний плюралізм, лібералізм - заміна ідеї конфлікту на ідею взаєморозуміння та діалогу, що створює основу для поглиблення розуміння сутності певних об'єктів.

6. «Недоконцептуалізованість понять» - відсутність однозначності у визначенні понять, що зумовлюється когнітивною складністю досліджуваної феноменології.

Отже, постнекласична наука створює підгрунтя для тлумачення прокрастинації як цілісного концепту, вплив якого прослідковується в усіх вимірах життя особистості. Аналіз сутності досліджуваного поняття у межах указаної парадигми, тобто на перетині різних галузей і дисциплін, дає змогу відзначити його багатомірність і детермінованість широким спектром психологічних, соціальних і фізіологічних чинників, що, з одного боку, породжує гносеологічну складність, а з другого - необхідність узгодження розрізнених наукових поглядів на природу цього феномену з метою поглиблення розуміння його сутності.

На другому рівні методології особливого значення у межах нашого дослідження набувають принципи системності, структурності та континуальності.

Підвищений інтерес до системного підходу серед представників різних наукових сфер зумовлюється його здатністю моделювати цілісність, а не зводити ціле до механіч(c) Zhuravliova Olena

DOI (article): https://doi.org/10.32626/2227-6246.2020-48.88-111 
ної суми окремих частин, що сприяє детальному осягненню складних об’єктів. Е. Маркарян стверджує, що зазначений принцип «є однією з фундаментальних стратегій наукового дослідження, історично викликаною необхідністю вивчення складно організованих систем адекватними пізнавальними засобами» (Маркарян, 1972: 77). Системна методологія, на думку Б. Ломова, відіграє роль інтегратора розрізненого психологічного знання, та саме вона «має стати інструментом синтезу даних, накопичених у численних психологічних дисциплінах, і подальшого розвитку загальної теорії психології» (Ломов, 1984: 104). В. Мерлін, висвітлюючи сутність застосування цього принципу до вивчення психічних процесів, акцентує увагу на неможливості залишатися у межах винятково методів і термінів психології. Науковець підкреслює наявність взаємозв'язку як безпосередньо між елементами самої особистості, так і їі взаємозалежність із навколишнім середовищем (Мерлин, 1986).

Системність як основу ефективного осягнення дійсності розглядав В. Вернадський. Із точки зору вченого, поділ наукової думки на окремі галузі є умовним, хоча і сприяє ефективнішому вирішенню окремих задач, виокремлюючи в них простіші елементи. Водночас, у якості ключової цілі дослідник указував необхідність створення єдиної картини світу (Вернадский, 2004). Окреслена ідея, на думку Л. Засєкіної, сьогодні активно втілюється у межах широкого спектра синергетичних досліджень, що організовуються за принципом конструювання парасольки: концептуальні ідеї, які лежать в основі різних підходів і теорій, об'єднуються в один стрижень предмета пізнання - людини. Отже, очевидною є узгодженість принципу системності з постнекласичною парадигмою, що склала вищий рівень філософської методології нашого дослідження (Засєкіна, 2005).

Слово «система» у перекладі з грецької тлумачиться як «ціле, що складається з частин». Інтерес до цього поняття з боку представників різних наукових галузей відобража-

(C) Zhuravliova Olena

DOI (article): https://doi.org/10.32626/2227-6246.2020-48.88-111 
ється у широкому колі підходів до його визначення. Досить часто у науковій літературі зустрічається дефініція, запропонована автором теорії систем Л. фон Берталанфі, який пропонує інтерпретувати це поняття як «сукупність взаємодіючих елементів» (Берталанфи, 1973). Однак дещо детальніше, на нашу думку, сутність цього терміна розкриває визначення, представлене В. Садовським, згідно з яким системою $є$ «впорядкована певним чином множина елементів, які взаємопов'язані між собою і створюють цілісну єдність» (Садовский, 1974: 173).

М. Роговін зауважив, що кожна система відповідає низці універсальних критеріїв (Роговин, 1977):

- є цілісністю, однак характеризується якісно новими властивостями, що не вичерпуються винятково особливостями частин, із яких вона формується;

- детермінується своєю функцією, яку називають системоутворюючою;

- перебуває в енергетичній та інформаційній взаємодії з навколишньою дійсністю;

- знаходиться у постійному процесі розвитку.

Дотримання принципу системності передбачає аналіз прояву властивостей досліджуваного об’єкта як на «метасистемному» (з грец. «meta» - над, після), так і на «субсистемному» (з лат. «sub» - під) рівнях.

У межах нашої наукової розвідки метасистемний вимір виявляється у вигляді єдності усіх компонентів, які функціонують як інтегральна властивість особистості - прокрастинація. Субсистемна площина представлена двома підструктурами (соціально-психологічною та біологічною, зміст яких детально розглядається нижче), а також складовими елементами, що утворюють кожну з цих підсистем.

Органічним доповненням системного принципу є структурний, який передбачає виявлення порядку елементів у системі, їі впорядкованість, розкриття поліструктурності (C) Zhuravliova Olena

DOI (article): https://doi.org/10.32626/2227-6246.2020-48.88-111 
об’єктів дослідження. Поняття «структура» (з лат. «structura» - будова) розглядаємо як внутрішню будову та спосіб взаємодії складових системи (Фролова, 1991). Отже, саме структура інтегрує окремі частини у єдність, в умовах інтенсивних зовнішніх впливів запобігає безладним деструктивним змінам елементів системи, сприяє утриманню її цілісності у межах певної якості. Водночас, наявність структури $\epsilon$ необхідною умовою для накопичення кількісних змін усередині системи, що є передумовою їі подальшого розвитку і перетворення.

Отже, застосування структурного аналізу об'єктів дослідження дає змогу:

- встановити інтенсивність і частоту зв'язків, що припадають на окремий елемент системи;

- виявити розгалужені та складнопідпорядковані типології взаємозв'язків складових між собою і з цілим;

- визначити співвідношення між інтернальними й екстернальними зв'язками, що свідчить про загальний рівень відкритості досліджуваної системи;

- вивчити можливі та допустимі (в сенсі збереження стабільності) стани макросистеми загалом.

Доцільність застосування структурного принципу при дослідженні прокрастинації зумовлюється специфікою будови цього концепту. Зазначені соціально-психологічний i біологічний виміри прокрастинації формуються з диференційованих елементів. Відтак, необхідною умовою деталізації сутності цього феномену є встановлення його внутрішньої структури, тобто взаємозв'язків між його складовими частинами.

Вагоме місце на цьому методологічному рівні організації нашого дослідження займає принцип континуальності (з грец. «continuum»- протяжний, безперервний), який відображає першопочаткову єдність множини властивостей прокрастинації та безперервність їх розвитку під дією впливу

(C) Zhuravliova Olena

DOI (article): https://doi.org/10.32626/2227-6246.2020-48.88-111 
широкого спектра інтернальних та екстернальних чинників. Тобто, у межах емпіричного вивчення можемо зобразити прокрастинацію у вигляді множини точок неперервної кривої, при цьому в кожній із сусідніх точок респонденти володіють однаковими характеристиками, але різною мірою їх вираженості. Отже, досліджуваний параметр розглядаємо як нестатичну характеристику особистості, яка схильна до кількісних трансформацій із плином часу. Однак, не дивлячись на можливі зміни, очевидна наявність певної інваріантної частини, що і створює підгрунтя для їі відокремлення від інших особистісних властивостей. Саме така інваріантна частина, на нашу думку, відображається у структурі прокрастинації.

Отже, з огляду на принцип континуальності процес формування прокрастинації характеризується незавершеністю. Окреслений підхід дає змогу виявити такі характеристики прокрастинації, як зв’язок із навколишньою дійсністю, певна хаотичність, багатомірність.

Використання принципів системності, структурності та континуальності при вивченні прокрастинації потребує виокремлення її системоутворюючих елементів і визначення специфіки взаємодії між ними. Це зумовило вибір конкретно-наукової методології дослідження, представленої біопсихосоціальною моделлю.

Виникнення цієї наукової концепції пов'язують з опублікованою в 1977 р. працею Дж. Енджела під назвою «Потреба у новій медичній моделі: виклик біомедицині». Аналізуючи основні положення класичного біомедичного підходу, автор критикує його ключові ідеї, що транслюють безумовний примат біологічних чинників над психосоціальними у контексті виникнення захворювання людини. Як наслідок, на думку науковця, розлади у роботі організму вважаються єдиною та достатньою умовою розвитку хвороби, дослідник-клініцист зосереджує увагу винятково на фізіологічних (C) Zhuravliova Olena

DOI (article): https://doi.org/10.32626/2227-6246.2020-48.88-111 
симптомах, що призводить до недооцінювання впливу психологічних чинників на загальний стан пацієнта. Аргументуючи свою позицію, Дж. Енджел представляє результати власних досліджень, які демонструють, що страх, злість, нехтування чи прив'язаність можуть здійснювати безпосередній фізіологічний вплив на організм i його розвиток (Фролова, 2008).

Саме 3 огляду на окреслені погляди, у якості альтернативи дуалістичній біомедичній моделі, що спонукала до встановлення чіткої межі між тілом, переживаннями та соціальним досвідом пацієнта, науковець запропонував альтернативну холістичну біопсихосоціальну модель, що передбачає вивчення трьох указаних вимірів життя особистості як комплементарних аспектів, тобто таких, що не взаємовиключають, а доповнюють один одного. Варто зауважити, що саме цей інтегральний підхід було покладено в основу розробки в Україні загальнодержавної програми охорони психічного здоров'я, що буде чинною до 2025 р.

Запропоновані Дж. Енджелом ідеї стосувалися, насамперед, проблематики здоров'я, але досить швидко набули популярності та використовуються серед представників різних галузей психологічного знання. Отже, окреслені наукові погляди створюють підгрунтя для тлумачення різних психологічних конструктів як результатів взаємодії психологічних, соціальних і біологічних чинників.

Визначення методологічних засад нашого дослідження дає змогу перейти до конструювання теоретичної моделі прокрастинації.

Грунтуючись на висвітлених методологічних принципах, прокрастинацію розглядаємо як особистісний конструкт, що на макросистемному рівні функціонує як багатомірне інтегральне стійке особистісне утворення, а в субсистемній площині представлене психосоціальною та біологічною підструктурами (рис. 1).

(C) Zhuravliova Olena

DOI (article): https://doi.org/10.32626/2227-6246.2020-48.88-111 


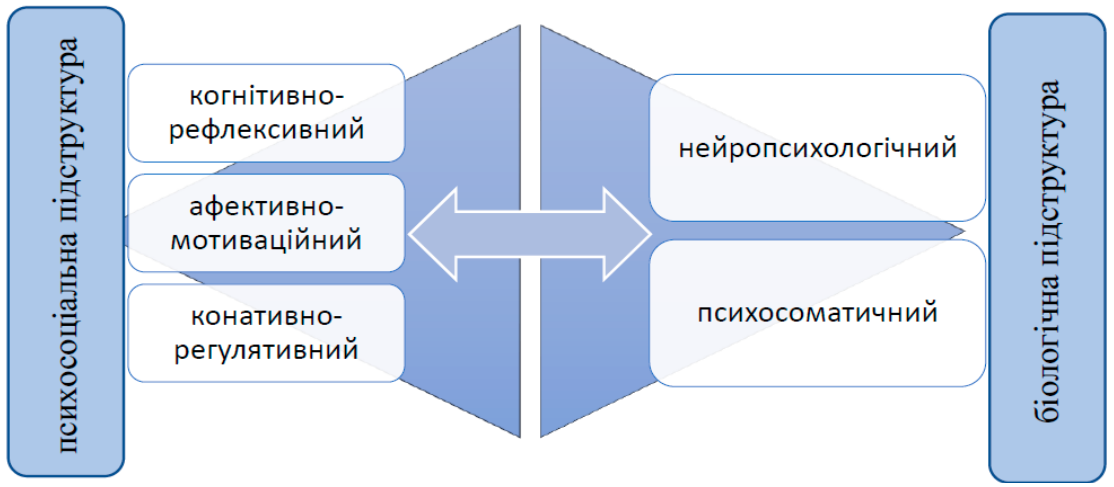

Puc. 1. Інтегральна модель особистості прокрастинатора

Психосоціальну площину прокрастинації розглядаємо як сукупність індивідуальних властивостей особистості, що формуються й трансформуються внаслідок включення людини у широке коло референтних груп і процесу соціалізації загалом.

Звертаючись до вивчення психологічного змісту структури особистості прокрастинатора, науковці акцентують увагу на різних аспектах. Деякі з них зосереджуються на емоційних переживаннях (Chabaud, Ferrand \& Maury, 2010), які супроводжують подібне зволікання, водночас у межах інших праць головним об'єктом наукового пошуку стає спосіб мислення (Karas \& Spada, 2009) або ж особливості поведінки (Van Eerde, 2003) осіб, схильних до відкладання важливих справ.

В окресленому контексті цікавими є ідеї Елліса й Кнауса, що склали основу запропонованої вченими раціонально-емотивно-поведінкової теорії, яка грунтується на припущені, відповідно до якого думки, почуття та дії не є розрізненими аспектами, а нерозривно пов'язаними комплементарними утвореннями (Ellis, 1991). 3 огляду на це, цілком погоджуємося з думкою Уотсона (Watson, 2001), що охоплення прокрастинацією мисленнєвих, емоційних і поведінкових (c) Zhuravliova Olena

DOI (article): https://doi.org/10.32626/2227-6246.2020-48.88-111 
проявів указує на комплексність соціально-психологічної природи цього феномену та визначає необхідність його вивчення з позиції не унітарності, а мультивимірності.

Відтак, у структурі психосоціальної складової прокрастинації виокремлюємо когнітивно-рефлексивний, емотивномотиваційний і конативно-регулятивний рівні.

Водночас, Ірунтуючись на біопсихосоціальній моделі в концептуалізації прокрастинації, зауважимо, що більшість учених, вивчаючи окреслену проблематику, зосереджується саме на їі психосоціальному вимірі. Адже, аналізуючи наукову літературу, фіксуємо, що автори, зазвичай, зорієнтовані на виявлення особистісних властивостей і соціальних умов, пов'язаних зі схильністю індивіда до зволікання. Натомість біологічні основи цього феномену, як правило, залишаються поза увагою дослідників.

Зазначимо, що у великій кількості наукових праць, представлених у сфері нейробіології, підкреслюється чіткий зв'язок схильності індивіда до зволікання з роботою різних ділянок кори головного мозку. Водночас кореляцію цієї особистісної диспозиції вчені все частіше фіксують не лише 3 кортикальним, а й психосоматичним рівнем функціонування особистості, підкреслюючи підвищену ймовірність виникнення у прокрастинаторів низки тілесних захворювань. 3 огляду на це, вважаємо доречним у структурі природнобіологічної складової сконструйованої нами моделі виокремлювати два рівні: нейрофізіологічний і психосоматичний.

\section{Висновки}

Отже, теоретичний аналіз наукових праць, присвячених проблематиці прокрастинації, заклав підвалини для розробки методологічної основи, необхідної для комплексного вивчення зазначеного феномену. Враховуючи висвітлені особливості постнекласичної наукової парадигми, принципи системності, структурності, континуальності та біопсихосоціального підходу, розглядаємо прокрастинацію

(C) Zhuravliova Olena

DOI (article): https://doi.org/10.32626/2227-6246.2020-48.88-111 
DOI: https://doi.org/10.32626/2227-6246.2020-48

2020. випуск 48

як особистісний конструкт, що функціонує як інтегральне стійке особистісне утворення. Структура цього феномену охоплює психосоціальну складову, що виявляється на когнітивно-рефлексивному, афективно-мотиваційному i конативно-регулятивному рівнях функціонування особистості, а також біологічну підструктуру, що містить нейрофізіологічний і психосоматичний рівні. Перспективи подальшого дослідження передбачають емпіричне вивчення запропонованої теоретичної моделі.

\section{Література}

Асмолов А. Г., Гусельцева М. С. Кому и как разрабатывать методологию психологии? Сибирский психологический журнал. 2015. № 55 . С. $6-45$.

Берталанфи фон Л. История и статус общей теории систем. Систелные исследования. Москва : Наука, 1973. 216 с.

Броннікова Л. В. Постнекласична наука: новий тип виробництва знання. Наукові праці Чорноморського державного університету імені Петра Могили колплексу «Києво-Могилянська академія». 2015. № 250. С. $30-33$.

Вернадский В. И. Биосфера и ноосфера. Москва : Айрис-пресс, 2004. $576 \mathrm{c.}$

Волков А. А., Назаров И. Н., Лукьянов А. С. Специфика предмета социально-психологического исследования сквозь призму постнеклассической рациональности. Фундалентальные исследования. 2015. № 2 (23). С. 5214-5218.

Воропаева Т. С., Чик А. А. Изучение коллективной памяти как фактора формирования национальной идентичности в рамках современного украиноведения. Сборник научных трудов SWorld ( $\Phi$ илософия и филология). 2015. URL : http://www.sworld.com.ua/ konferm2/287.pdf.

Горстко А. Б. Познакомтесь с математическим моделированием. Москва : Знания, 1994. $160 \mathrm{c.}$

Грицанов А. А. Новейший философский словарь. Минск : Скакун, 1998. $896 \mathrm{c}$.

Гусельцева М. С. Постнеклассическая рациональность в культурной психологии. Психологический журнал. 2005. № 6. С. 5-15.

Дмитриева Ю. А., Грязева-Добшинская В. Г. Метод моделирования в социальной психологии. Вестник Южно-Уральского государственного университета. 2013. № 1 (6). С. 18-26.

(C) Zhuravliova Olena

DOI (article): https://doi.org/10.32626/2227-6246.2020-48.88-111 
Засєкіна Л. В. Структурно-функиіональна організація інтелекту. Острог : Вид-во Національного університету «Острозька академія», 2005. 370 с.

Иноземцев В. А., Удовик В. Е. Информационно-компьютерная революция и становление информационного общества. Исторические, философские, политические и юридические науки, культурология и искусствоведение. Вопросы теории и практики. 2011. № 8 (4). C. 69-74.

Ломов Б. Ф. Методологические и теоретические проблемы психологии. Москва : Наука, 1984. 444 с.

Мазилов В. А. Научная психология: тернистый путь к интеграции. Ярославль : МАПН, 2001. 237 с.

Маркарян Э. С. Системное исследование человеческой деятельности. Вопросы философии. 1972. № 10. С. 77-87.

Мерлин В. С. Очерк интегрального исследования индивидуальности. Москва : Педагогика, 1986. 256 с.

Нестик Т. А., Ж уравлев А. Л., Юревич А. В. Прогноз развития психологической науки и практики к 2030 г. Ярославский педагогичес кий вестник. 2016. № 5. С. 177-192.

Никандров В. В. Экспериментальная психология: учебное пособие. Санкт-Петербург : Речь, 2003. 480 с.

Радзиховский Л. А. Логический анализ и проблема понимания в психологии. Вопросы психологии. 1989. № 5. С. 99-106.

Рибалка В. В. Методологічні питання наукової психології (досвід особистісно центрованої систематизації категоріально-поняттєвого апарату). Київ : Ніка-Центр, 2003. 204 с.

Роговин М. С. Структурно-уровневые теории в психологии: методологические основы. Ярославль : ЯрГУ, 1977. 79 с.

Садовский В. Н. Основания общей теории систем: логико-методологический анализ. Москва : Наука, 1974. 280 с.

Смирнов С. Д. Методологический плюрализм и предмет психологии. Вопросы психологии. 2005. № 4. С. 3-8.

Татенко В. О. Сучасна психологія: теоретично-летодологічні проблели. Київ : Вид-во Нац. авіац. ун-ту «НАУ-друк», 2009. 298 с.

Фролова И. Т. Философский словарь. Москва : Политиздат, 1991. 560 с.

Хоружа Л. Л. Теоретичні засади формування етичної компетентності майбутніх учителів початкових класів: дис. д-ра пед. наук: 13.00.04. Київ, 2004. 365 с.

Черникова И. В. Постнеклассическая наука и философия процесса. Томск : НТЛ, 2007. 252 с.

Штрофф В. А. Моделирование и философия. Москва : Наука, 1996. 301 c.

(C) Zhuravliova Olena

DOI (article): https://doi.org/10.32626/2227-6246.2020-48.88-111 
DOI: https://doi.org/10.32626/2227-6246.2020-48

Юдин Э. Г. Системный подход и принцип деятельности: методологические проблемы современной науки. Москва : Наука, 1978. 391 с.

Chabaud, P., Ferrand, C., \& Maury, J. (2010). Individual differences in undergraduate student athletes: The roles of perfectionism and trait anxiety perception of procrastination behavior. Social Behavior \& Personality: An International Journal, 38, 1041-1056.

Ellis, A. (1991). The revised ABC's of rational-emotive therapy (RET). Journal of Rational-Emotive and Cognitive-Behavior Therapy, 9, 139-172.

Karas, D., \& Spada, M. M. (2009). Brief cognitive-behavioral coaching for procrastination: A case series. Coaching: An International Journal of Theory, Research \& Practice, 2, 44-53.

Van Eerde, W. (2003). Procrastination at work and time management training. The Journal of Psychology, 137, 421-434.

Watson, D. C. (2001). Procrastination and the five-factor model: A facet level analysis. Personality and Individual Differences, 30, 149-158.

\section{References}

Asmolov, A. G., \& Guseltseva, M. S. (2015). Komu i kak razrabatyvat metodologiiu psikhologii? [To whom and how to develop a methodology of psychology?]. Sibirskii psikhologicheskii zhurnal - Siberian journal of psychology, 55, 6-45 [in Russian].

Bertalanfi von, L. (1973). Istoriia i status obshchei teorii sistem [History and status of the general theory of systems]. Sistemnyie issledovaniia - System research. Moskva : Nauka [in Russian].

Bronnikova, L. V. (2015). Postneklasychna nauka: novyi typ vyrobnytstva znannia [Post-nonclassical science: a new type of knowledge production]. Naukovi pratsi Chornomorskoho derzhavnoho universytetu imeni Petra Mohyly kompleksu «Kyievo-Mohylianska akademiia»Scientific researches of Petro Mohyla Blach Sea National University at the complex "Kyiv-Mohyla Academy», 250, 30-33 [in Ukrainian].

Vernadskii, V. I. (2004). Biosfera i noosfera [Biosphere and noosphere]. Moskva : Airis Press [in Russian].

Volkov, A. A., Nazarov, I. N., \& Lukianov, A. S. (2015). Spetsifika predmeta sotsialno-psikhologicheskogo issledovaniia skvoz prizmu postneklassicheskoi ratsionalnosti [The specificity of the subject of socio-psychological research through the prism of post-non-classic rationality]. Fundamentalnyie issledovaniia - Fundamental researches, 2 (23), 5214-5218 [in Russian].

Voropaieva, T. S., \& Chik, A. A. (2015). Izucheniie kollektivnoi pamiati kak faktora formirovaniia natsionalnoi identichnosti $\mathrm{v}$ ramkakh (C) Zhuravliova Olena

DOI (article): https://doi.org/10.32626/2227-6246.2020-48.88-111 
sovremennogo ukrainovedeniia [The study of collective memory as a factor in the formation of national identity in the framework of modern Ukrainian studies]. Sbornik nauchnykh trudov SWorld (Filosofiia $i$ filologiia) - Collection of scientific papers SWorld (Philosophy and Philology). Retrieved from http://www.sworld.com.ua/ konferm2/287.pdf [in Russian].

Gorstko, A. B. (1994). Poznakomtes s matematicheskim modelirovaniem [Get to know mathematical modeling]. Moskva : Znaniia [in Russian].

Gritsanov, A. A. (1998). Noveishii filosofskii slovar [The latest philosophical dictionary]. Minsk : Skakun [in Russian].

Guseltseva, M. S. (2005). Postneklassicheskaia ratsionalnost v kulturnoi psikhologii [Post-non-classical rationality in cultural psychology]. Psikhologicheskii zhurnal - Psychological Journal, 6, 5-15 [in Russian].

Dmitrieva, Yu. A., \& Griazeva-Dobshinskaia, V. G. (2013). Metod modelirovaniia $\mathrm{v}$ sotsialnoi psikhologii [The modeling method in social psychology]. Vestnik Yuzhno-Uralskogo gosudarstvennogo universiteta - Bulletin of the South Ural State University, 1 (6), 18-26 [in Russian].

Zasiekina, L. V. (2005). Strukturno-funktsionalna orhanizatsiia intelektu [Structural and functional organization of intellect]. Ostroh : Vyd-vo Natsionalnoho universytetu «Ostrozka akademiia» [in Ukrainian].

Inozemtsev, V. A., \& Udovik, V. E. (2011). Informatsionno-kompiuternaia revoliutsiia i stanovleniie informatsionnogo obshchestva [Information and computer revolution and information society formation]. Istoricheskiie, filosofskiie, politicheskiie i yuridicheskiie nauki, kulturologiia $i$ iskusstvovedeniie. Voprosy teorii i praktiki - Historical, philosophical, political and legal sciences, cultural studies and art history. Questions of theory and practice, 8 (4), 69-74 [in Russian].

Lomov, B. F. (1984). Metodologicheskiie i teoreticheskiie problemy psikhologii [Methodological and theoretical problems of psychology]. Moskva : Nauka [in Russian].

Mazilov, V. A. (2001). Nauchnaia psikhologiia: ternistyi put $k$ integratsii [Scientific psychology: the thorny path to integration]. Yaroslavl : MAPN [in Russian].

Markarian, E. S. (1972). Sistemnoie issledovaniie chelovecheskoi deiatelnosti [Systematic study of human activity]. Voprosy filosofii-Questions of philosophy, 10, 77-87 [in Russian].

Merlin, V. S. (1986). Ocherk integralnogo issledovaniia individualnosti [Essay on the integral study of personality]. Moskva : Pedagogika [in Russian].

(c) Zhuravliova Olena

DOI (article): https://doi.org/10.32626/2227-6246.2020-48.88-111 
Nestik, T. A., Zhuravlev, A. L., \& Yurevich, A. V. (2016). Prognoz razvitiia psikhologicheskoi nauki i praktiki k $2030 \mathrm{~g}$. [The perspective of development of psychological science and practice by 2030]. Yaroslavskii pedagogicheskii vestnik - Yaroslavl Pedagogical Bulletin, 5, 177-192 [in Russian].

Nikandrov, V. V. (2003). Eksperimentalnaia psikhologiia [Experimental psychology]. Sankt-Peterburg : Rech [in Russian].

Radzikhovskii, L. A. (1989). Logicheskii analiz i problema ponimaniia v psikhologii [Logical analysis and the problem of understanding in psychology]. Voprosy psikhologii - Psychology issues, 5, 99-106 [in Russian].

Rybalka, V. V. (2003). Metodolohichni pytannia naukovoi psykholohii (dosvid osobystisno tsentrovanoi systematyzatsii katehorialno-poniattievoho aparatu) [Methodological Issues of Science Psychology (the experience of personality oriented systematization of categorically-notion equipment)] Kyiv : Nika-Tsentr [in Ukrainian].

Rogovin, M. S. (1977). Strukturno-urovnevyie teorii v psikhologii: metodologicheskiie osnovy [Structural-level theories in psychology: methodological foundations]. Yaroslavl: YarGU [in Russian].

Sadovskii, V. N. (1974). Osnovaniia obshchei teorii sistem: logiko-metodologicheskii analiz [The foundations of the general theory of systems: logical-methodological analysis]. Moskva : Nauka [in Russian].

Smirnov, S. D. (2005). Metodologicheskii pliuralizm i predmet psikhologii [Methodological pluralism and the subject of psychology]. Voprosy psikhologii - Psychology issues, 4, 3-8 [in Russian].

Tatenko, V. O. (2009). Suchasna psykholohiia: teoretychno-metodolohichni problemy [Modern psychology: theoretical and methodological problems]. Kyiv : Vyd-vo Nats. aviats. Un-ty «NAU-Druk» [in Ukrainian].

Frolova, I. T. (1991). Filosofskii slovar [Philosophical Dictionary]. Moskva : Politizdat [in Russian].

Khoruzha, L. L. (2004). Teoretychni zasady formuvannia etychnoi kompetentnosti maibutnikh uchyteliv pochatkovykh klasiv [Theoretical principles of ethical competence development for future primary school teachers]. Extended abstract of doctor's thesis. Kyiv [in Ukrainian].

Chernikova, I. V. (2007). Postneklassicheskaia nauka i filosofiia protsessa [Post-non-classical science and philosophy of process]. Tomsk : NTL [in Russian].

Shtroff, V. A. (1996). Modelirovaniie i filosofiia [Modeling and philosophy]. Moskva : Nauka [in Russian].

(c) Zhuravliova Olena

DOI (article): https://doi.org/10.32626/2227-6246.2020-48.88-111 
Yudin, E. G. (1978). Sistemnyi podkhod i printsip deiatelnosti: metodologicheskiie problemy sovremennoi nauki [Systematic approach and principle of activity: methodological problems of modern science]. Moskva : Nauka [in Russian].

Chabaud, P., Ferrand, C., \& Maury, J. (2010). Individual differences in undergraduate student athletes: The roles of perfectionism and trait anxiety perception of procrastination behavior. Social Behavior \& Personality: An International Journal, 38, 1041-1056.

Ellis, A. (1991). The revised ABC's of rational-emotive therapy (RET). Journal of Rational-Emotive and Cognitive-Behavior Therapy, 9, 139-172.

Karas, D., \& Spada, M. M. (2009). Brief cognitive-behavioral coaching for procrastination: A case series. Coaching: An International Journal of Theory, Research \& Practice, 2, 44-53.

Van Eerde, W. (2003). Procrastination at work and time management training. The Journal of Psychology, 137, 421-434.

Watson, D. C. (2001). Procrastination and the five-factor model: A facet level analysis. Personality and Individual Differences, 30, 149-158.

\section{Журавльова Олена. Методологічні засади дослідження феномену прокрастинації}

\section{АНОТАЦІЯ}

Автором обгрунтовано актуальність вивчення прокрастинації як стійкого особистісного конструкту. Окреслено наслідки підвищеної схильності індивіда до прояву дилаторних поведінкових реакцій.

Метою статmі є конструювання теоретико-методологічної бази для комплексного дослідження феномену прокрастинації. Основними методами дослідження слугували теоретичний аналіз і моделювання, що склали основу для визначення структури зазначеної диспозиції.

Результати теоретичного вивчення проблематики вказують на необхідність тлумачення прокрастинації як цілісного концепту, вплив якого прослідковується в усіх вимірах життя особистості. Аналіз сутності досліджуваного поняття дає змогу відзначити його багатомірність і детермінованість широким спектром психологічних, сочіальних і фізіологічних чинників. Основу для створення моделі особистості прокрастинатора склали засади постнекласичної наукової парадигми, принципи системності, структурності, континуальності та біопсихосоціального підходу Дж. Енджела. 3 огляду на визначену методологічну

(C) Zhuravliova Olena

DOI (article): https://doi.org/10.32626/2227-6246.2020-48.88-111 
DOI: https://doi.org/10.32626/2227-6246.2020-48

базу, автор зазначає, що прокрастинація на макросистемному рівні функціонує як багатомірне інтегральне стійке особистісне утворення, а в субсистемній площині представлена психосоціальною та біологічною підструктурами.

Психосоціальна площина прокрастинації розглядається як сукупність індивідуальних властивостей особистості, що формуються й трансформуються внаслідок включення людини у широке коло референтних груп і процесу сочіалізації загалом. Із точки зору автора, цей вимір індивіда, схильного до зволікання, виявляється у способі його мислення, емоційних переживаннях та особливостях поведінки. Відтак, у межах психосоціальної площини виокремлюються когнітивно-рефлексивний, афективно-мотиваційний і конативно-регулятивний рівні функціонування прокрастинатора.

Біологічна підструктура містить два компоненти: нейрофрізіологічний (специфічні особливості в активності ділянок кори головного мозку осіб, схильних до відтермінування важливих справ) і психосоматичний (специфічні соматичні порушення, пов'язані зі схильністю індивіда до прокрастинації).

Висновок. Отже, було сформовано інтегральну багаторівневу модель прокрастинації як стійкого особистісного конструкту, що потребує подальшої емпіричної перевірки.

Ключові слова: прокрастинація, системність, структурність, континуальність, психосоціальна та біологічна підструктура.

\section{Журавлёва Елена. Методологические основы исследования феномена прокрастинации}

\section{АННОТАЦИЯ}

Автором обосновано актуальность изучения прокрастинации как устойчивого личностного конструкта. Указано последствия повышенной склонности индивида к проявлению дилаторных поведенческих реакций.

Целью статьи является конструирование теоретико-методологической базы для комплексного исследования феномена прокрастинации. Основными методами исследования послужили теоретический анализ и моделирование, которые составили основу для изучения структуры данной диспозиции.

(C) Zhuravliova Olena

DOI (article): https://doi.org/10.32626/2227-6246.2020-48.88-111 
Результаты теоретического изучения проблематики указывают на необходимость определения прокрастинации как целостного концепта, влияние которого прослеживается во всех аспектах жизни личности. Анализ сущности исследуемого понятия позволяет отметить его многомерность и детерминированность широким спектром психологических, социальных и физиологических факторов. Основу для создания модели личности прокрастинатора составили принципы постнеклассической научной парадигмы, принципы системности, структурности, континуальности и биопсихосоциального подхода Дж. Энджела. Учитывая определенную методологическую базу, автор отмечает, что прокрастинация на макросистемном уровне функционирует как многомерное интегральное устойчивое личностное образование, а в субсистемной плоскости представлена психосоциальной и биологической подструктурами.

Психосоциальная плоскость прокрастинации рассматривается как совокупность индивидуальных свойств личности, которые формируются и трансформируются в результате включения человека в широкий круг рефрерентных групп и прочесса социализации в целом. С точки зрения автора, указанное измерение индивида, склонного к откладыванию, проявляется в образе его мышления, эмоциональных переживаниях и особенностях поведения. Следовательно, в пределах психосоциальной плоскости выделяются когнитивно-рефлексивный, аффрективно-мотивационный и конативно-регулятивный уровни функционирования прокрастинатора.

Биологическая подструктура содержит два компонента: нейрофизиологический (специфические особенности активности участков коры головного мозга лии, склонных к отсрочке важных дел) и психосоматический (специфические соматические нарушения, связанные со склонностью индивида к прокрастинации).

Вывод. Таким образом, была сформирована интегральная многоуровневая модель прокрастинации как устойчивого личностного конструкта, которая требует дальнейшей эмпирической проверки.

Ключевые слова: прокрастинация, системность, структурность, континуальность, психосоциальная и биологическая подструктура.

Original manuscript received January 26, 2020

Revised manuscript accepted March 05, 2020

(C) Zhuravliova Olena

DOI (article): https://doi.org/10.32626/2227-6246.2020-48.88-111 